\title{
TRÊS POEMAS DE HAROLDO DE CAMPOS EM TRADUÇÃO
}

TRADUZIDOS POR ECLAIR ANTONIO ALMEIDA FILHO E JOSINA NUNES RONCISVALLE 


\title{
TRÊS POEMAS DE HAROLDO DE CAMPOS EM TRADUÇÃO
}

\author{
Traduzido por: \\ Eclair Antonio ALMEIDA FILHO ${ }^{1}$ \\ Doutor em Letras (USP) \\ Professor Adjunto na Universidade de Brasília (UnB) \\ Brasília, Distrito Federal, Brasil \\ eclair.filho@hotmail.com \\ Josina Nunes RONCISVALLE ${ }^{2}$ \\ Doutoranda em Literatura (UnB) \\ Brasília, Distrito Federal, Brasil \\ josinanunes.nut@gmail.com
}

S três poemas aqui vertidos para o francês constam do livro Xadrez de Estrelas:
percurso textual $1949-1974$, da seção "Auto do Possesso", de Haroldo de
Campos.

\section{Rito de Outono}

No mês propício as virgens babilônicas

Tecem guirlandas em louvor de Ishtar.

Olha os seus rostos contornando o templo,

Côdeas de luz na lápide do altar.

Tua flor, Senhora, de lilases e álcool, A dispersavas pelo boulevard.

Touros alados crescem no caminho:

Tecei guirlandas para o mês de Ishtar!

Thammuz é o tempo. As virgens babilônicas Esperam sempre, sem jamais cansar. Joguei moedas sobre os teus joelhos. Lilases e álcool. Tua flor. Ishtar.

\section{Rite d'Automne}

Au mois propice les babyloniennes vierges Tissent des guirlandes en l'honneur d'Ishtar. Regarde leurs visages au pourtour du temple, Croûtes de lumière sur la pierre d'autel.

Voilà !

Ta fleur, Dame, de lilas et d'alcool, L'éparpillais le long du boulevard.

Taureaux ailés pulsent sur le chemin :

Tissez des guirlandes pour le mois d'Ishtar !

Thammuz, c'est le temps. Les babyloniennes vierges

Attendent toujours mais ne se lassent pas Je jetai des monnais sur tes genoux.

Lilas et alcool. Ta fleur. Ishtar. 


\section{Lamento sobre o lago de Nemi}

O azar é um dançarino nu entre os alfanjes. Na praia, além do rosto, a corola das mãos.

Chama teu inimigo. O azar é um dançarino. Reúne os seus herdeiros e proclama o Talião.

A virgem que encontrei coroada de rainúnculos

Não era - assim o quis - a virgem que encontrei.

O azar é um dançarino: teme os seus alfanjes.

Amanhã serei morto, mas agora sou rei.

$\mathrm{Nu}$, entre os alfanjes, coroado de rainúnculos,

Chama o teu inimigo e a virgem que encontrei.

Na praia, além do rosto, eu agora estou morto.

O azar é um dançarino. Amanhã serás rei.

\section{Plainte sur le lac de Nemi}

Le hasard est un danseur nu parmi les alfanges.

Sur la plage, en plus du visage, la corolle de ses mains

Appelle ton ennemi. Le hasard est un danseur.

Rassemble ses héritiers et proclame le Talion.

La vierge que j'ai trouvé couronnée de renoncules

n'était - ainsi le voulut-il - la vierge trouvée par moi.

Le hasard est un danseur : crains ses alfanges.

Demain je serai mort, mais à présent, je suis roi.

$\mathrm{Nu}$, parmi les alfanges, couronné de renoncules,

Appelle ton ennemi et la vierge trouvée par moi.

Sur la plage, en plus du visage, à présent je suis mort.

Le hasard est un danceur. Demain tu seras roi. 


\section{Vinha Estéril}

Sed fugit interea, fugit irreparabile tempus, singula dum capti circumvectamur amoré.

Virgílio

Vede:

a grande deusa vegetal de lábios de ametista de novo sobre um chão aos poucos

inclemente;

e como, das axilas tufam as papoulas

e os pés, como desbrugam uvas sumarentas.

Vede: os leopardos dominando as fêmeas nas touças, onde evola o almíscar predileto; e as éguas inflamadas, e os maduros flancos vertendo o áspero humor que os mágicos

\section{Vigne Stérile}

Voyez:

La grande déesse végétale aux lèvres d'amethyste

À nouveau sur un sol petit à petit inclément ; Et comment, des aisselles, gonflent les pavots

Et les pieds, comment épluchent raisins jussantes.

Voyez : les léopards en sourmontant les femmelles

Dans les buissons, d'où s'envole le musc de prédilection ;

Et les poulinières enflammées, et les mûrs flancs augurent.

É o tempo em que lateja a prata vigorada, C'est le temps où frémit l'argent gaillard, e o ouro encanecido arrasta seus grilhões. No arco do horizonte um alaúde vibra a música serena e túmida das frondes. Et l'or grisonné emporte les chaînes. Dans l'arc de l'horizon un luth vibre La musique séreine et tumescente des frondes.

Tu só não compartilhas, ânfora selada. Seule tu ne partages pas, anphore scellée. Teu lúbrico cabelo em trança modestíssima apanhas, nua e sóbria no jardim votivo.

Ton lubrique cheveu à trop modeste tresse Tu ramasses, nue et sobre dans le jardin votif. 
E as pombas não arrulham cópulas silvestres Et les colombes ne roucoulent de sylvestres aos beirais dormidos (contam que as copulations

cegaste);

Aux franges assoupies (dit-on que tu les

e o sol de abril tortura o teu monte de vênus, aveuglas) ;

onde, em si mesma exausta, uma tulipa Et le soleil d'avril torture ton mont de vênus,

esfolha

Où, en soi-même épuisée, une tulipe effeuille

púbere e cruenta.

Grège et pubère.

${ }^{1}$ Lattes Eclair Antonio Almeida Filho. Disponível em: http://lattes.cnpq.br/3369799579487169

${ }^{2}$ Lattes Josina Nunes Roncisvalle. Disponível em: http://lattes.cnpq.br/6040953275075337

RECEBIDO EM: 29 de julho de 2015

ACEITO EM: 20 de agosto de 2015 